\title{
Evaluating emplacement temperature of a 1000-year sequence of mass flows using paleomagnetism of their deposits at Mt. Taranaki, New Zealand
}

\author{
Geoffrey A. Lerner ${ }^{\star \alpha}$, Shane J. Cronin ${ }^{\alpha}$, Gillian M. Turner ${ }^{\beta}$ \\ ${ }^{\alpha}$ School of Environment, University of Auckland, Private Bag 92019, Auckland 1142, New Zealand. \\ $\beta$ School of Chemical and Physical Sciences, Victoria University of Wellington, PO Box 600, Wellington 6140, New Zealand
}

\begin{abstract}
Temperature can be an important characteristic used to distinguish primary pyroclastic density currents or blockand-ash flows from other collapses not primarily related to an eruption, and also governs the type and level of hazard presented by these mass flows. We examined several mass-flow deposits within the AD1000-1800 Maero Formation at Mt. Taranaki, New Zealand, for field characteristics of hot emplacement-such as the presence of charcoal, baking of soils, or gas-elutriation piping - and conducted a paleomagnetic study of their thermoremanent magnetization (TRM) to determine emplacement temperatures. Results show that the majority of the deposits result from block-and-ash flows emplaced over $\sim 500^{\circ} \mathrm{C}$. Some of these deposits were indistinguishable in the field from a re-worked or low-temperature emplaced lahar or landslide deposit, indicating that sedimentary features are not a clear determinant of high emplacement temperature. The high emplacement temperatures suggest that the time between dome emplacement and collapse during this period was usually brief ( $<30$ years), with some events consisting of rapid and repeated growth and collapse of lava domes, possibly within the same prolonged lava effusion episode.
\end{abstract}

Keywords: Volcano; Pyroclastic flow; Block-and-ash flow; Paleomagnetism; Hazard

\section{INTRODUCTION}

Block-and-ash flows (BAFs) are among the greatest hazards presented by growing lava domes at active volcanoes. The high speed and temperature of this type of pyroclastic density current (PDC) makes them deadly and destructive over distances commonly 5 to $\sim 15 \mathrm{~km}$ from the source. They may occur in individual episodes over a long period of a volcano's eruptive record or in quick succession over a short span of activity as in the cases of Mt. Sinabung since 2013 [Nakada et al. 2017] and of Soufrière Hills volcano from 1996 to 1998 [Calder et al. 2002]. In both these cases, block-andash flows and eruptions triggered by the dome collapse necessitated major, largely successful evacuations, but still resulted in casualties [Robertson et al. 2000; Andreastuti et al. 2017].

When there is no historical record of eruptions at an active stratovolcano, proper assessment of BAF hazard to the surrounding areas begins with careful observation and analysis of past volcanic deposits. The goal of this analysis is to understand the temperature, frequency, and location of previous mass flows at the volcano in order to project future hazard. A major difficulty with this analysis is that BAF deposits are often interbedded with-and difficult to distinguish from-

${ }^{*}$ Corresponding author: g.lerner@auckland.ac.nz lahar, rockfall, and other colluvial deposits with similar lithology [Brown and Andrews 2015]. Uncertainty over deposit type is a hindrance to evaluating the sequence of past activity. BAF deposits from the same volcano can even vary between each other based on mode of transport and deposition, as well as the state of the dome at collapse (e.g. if it represents several extrusion events, or has areas of intense oxidation). These features lead to different surface characteristics and lithology in known hot-emplaced BAF deposits [Charbonnier and Gertisser 2008; Cronin et al. 2013].

Characteristics associated with high-temperature BAF deposits include bread-crusted or coolingfractured clasts, angular clasts, gas elutriation pipes, carbonised vegetation, monolithologic clasts, and a homogenous ash matrix composed of similar material to the clasts (Figure 1). Under the most favourable circumstances for identification, cold debris flow deposits or rock fall deposits tend to have a greater variety of clast lithologies, a more diverse matrix, possibly rounded clasts and other features associated with water, including mud coatings on clasts [Uehara et al. 2015]. Charcoal can also be re-deposited by reworking of BAF deposits, and the lithology, clast roundness, and sorting may be changed very little by localised re-deposition. Further, gas elutriation pipes have also been found in both hot and cold deposits 

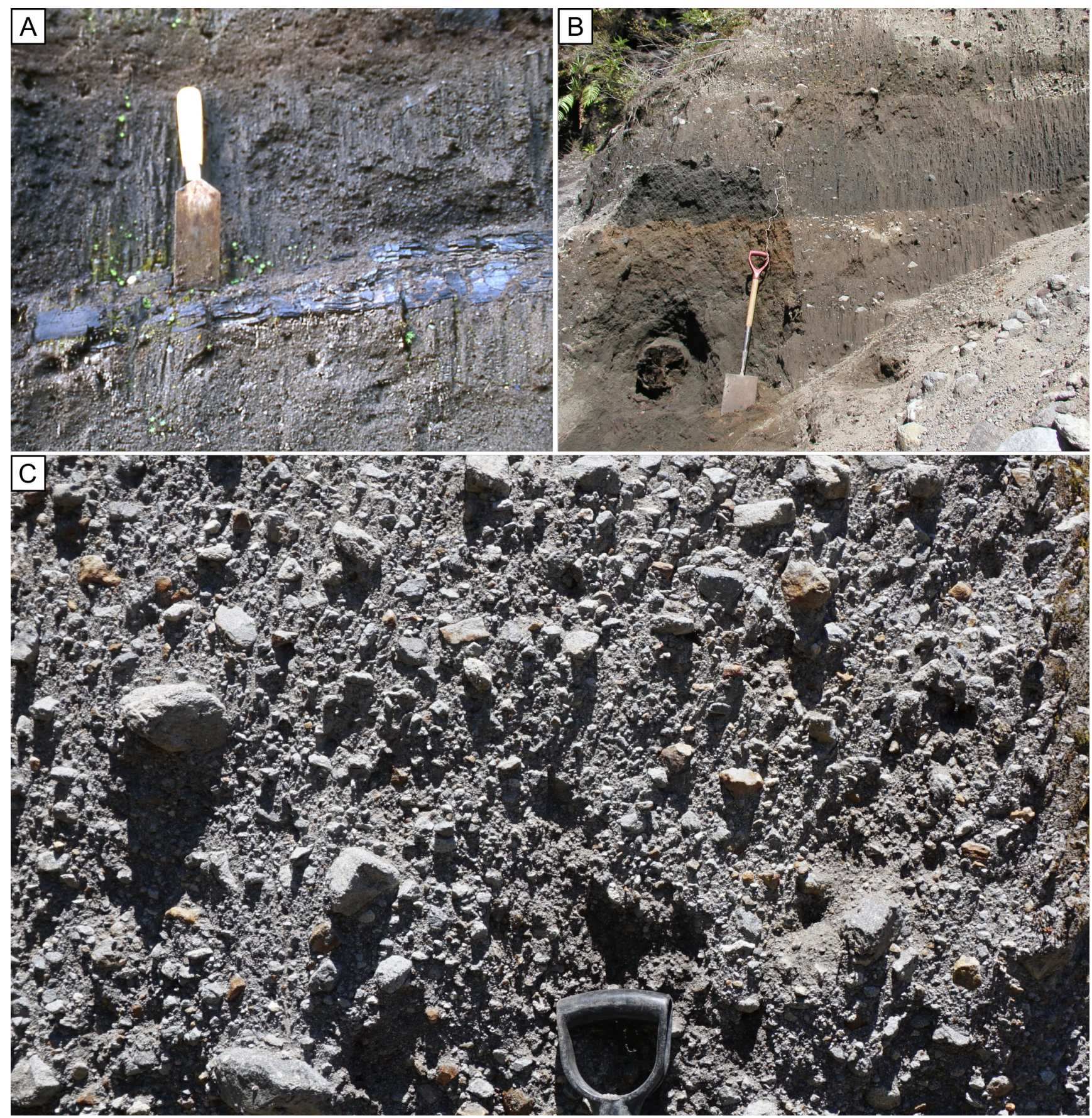

Figure 1: Photos of typical block-and-ash flow deposit characteristics: [A] charcoalised tree branch. [B] BAF sequence with the lowest brown unit containing a charred tree trunk and oxidised reddish upper contact. [C] BAF deposit typical view in outcrop-massive, poorly sorted, with angular and fractured, mostly grey andesite clasts. Examples are from the Waiweranui unit, Maero Formation, Mt. Taranaki.

under certain conditions [Druitt 1995]. Volcanic mass flows are deposited over a spectrum of temperatures, and deposition and preservation patterns are erratic, which also leads to many cases where sedimentary properties are ambiguous indicators of temperature. Dome collapse PDCs and BAFs from hot lava domes maintain temperatures over $800^{\circ} \mathrm{C}$, but can also be deposited at temperatures between $100-500^{\circ} \mathrm{C}$ [Tanaka et al. 2004]. Water-saturated debris flows formed from BAFs remobilised by water or channelised in river catchments can also reach temperatures over $100^{\circ} \mathrm{C}$, although they are most typically at ambient temperature [Thouret and Lavigne 2000]. Sedimentary characteristics usually considered diagnostic of one type of pyroclastic deposit may not be universal or may be difficult to interpret in the field [Fisher and Schmincke 2012; Vallance and Iverson 2015] Other indicators of heat in BAF deposits often include weakly 
oxidised upper portions of deposits: showing reddish or pinkish hues associated with haematite formation [Cronin et al. 2013]. Bedding within BAF deposits and related debris flows is also often similar, with the preservation of weak horizontal fabric in both types, clast trains, and coarse-clast rich unit tops [Schwarzkopf et al. 2005; Cronin et al. 2013]. Debris flow deposits, formed by remobilisation of BAF deposits in fans of self-similar materials, frequently have characteristics indistinguishable from their source units, even though they were redeposited farther from their original emplacement point during and after cooling [Brown and Andrews 2015].

Distinguishing eruptive and secondary mass flow deposits within volcanic sequences is vital for understanding volcanic history and reconstructing eruption scenarios for emergency managers. In particular it is important to reassemble the history and duration of dome effusion episodes and distinguish the active phase of an eruptive episode from post-event processes. At Mt. Taranaki in New Zealand, the past 1000 years of activity (the Maero Eruptive Period) present as a sequence of volcanic deposits forming a major fan on the northwest flanks of the volcano. The fan contains a variety of deposit textures and sedimentary features, but generally similar dense lava clasts are the dominant lithology. Deposits are interpreted as resulting mainly from hot lava dome collapses [Platz et al. 2012]. However, without a complete understanding of the temperature at which these deposits were emplaced, it is impossible to determine whether all deposition units were formed from hot dome collapses, whether any are posteruption reworked units, and to interpret aspects important for hazard managers, such as the duration of dome-forming episodes and the numbers of collapses during each episode. The accessibility of the full Maero Formation sequence at many locations on the western flanks of the volcano allows for thorough analysis of the emplacement temperatures of deposits from this eruptive period. Insights gained from volcanic sequences at Taranaki can be readily applied to other stratovolcanoes known to undergo similar periods of ongoing dome growth and collapse (e.g. Merapi, Indonesia; Colima, Mexico).

There are few methods available to assess the emplacement temperature of PDCs. Direct measurements are possible in rare cases within PDC deposits shortly after emplacement [e.g. Cole et al. 2002]. For fullycooled older deposits, analysis of reflectance of thin sections made from charcoal can provide emplacement temperature estimates [Scott and Glasspool 2005]. Reflectance, however, is a function of both temperature and duration of heating, and thus cannot provide a maximum emplacement temperature estimate unless the heating duration of the deposit is known [Scott and Glasspool 2005]. Alternatively, hydrogen/carbon $(\mathrm{H} / \mathrm{C})$ ratios in charcoal found in PDC deposits can be correlated to duration and temperature of heating to estimate emplacement temperatures [Sawada et al. 2000]. At lower temperatures of emplacement, vegetation dieback may also be used as a proxy for temperature [Efford et al. 2014].

Paleomagnetic emplacement temperature methods can be used on any magnetic-mineral bearing deposit with sufficient clast or matrix material and can be used to distinguish PDCs from reworked and lahar deposits [Paterson et al. 2010; Uehara et al. 2015]. This method may provide accurate estimates of emplacement temperature up to the Curie temperature of the constituent ferrimagnetic minerals (usually $\sim 500-600^{\circ} \mathrm{C}$ ), but not beyond. Results may also vary within a deposit; e.g. clasts taken from the top or bottom of the deposit may have different thermal profiles than those from the center due to stratigraphic variation of titanomagnetite within PDC deposits [Bowles et al. 2018].

\section{GeOLOGIC BACKGROUND}

Mt. Taranaki is a $2518 \mathrm{~m}$-high stratovolcano located on the west of the North Island of New Zealand (Figure 2). It is the youngest and only active volcano of a lineament and has erupted since approximately $170 \mathrm{ka}$ [Neall et al. 1986]. Above $1400 \mathrm{~m}$ elevation, the upper cone was constructed over the past $\sim 14 \mathrm{ky}$ [Neall et al. 1986; Turner et al. 2011]. Over the past $30 \mathrm{ky}$, volcanism has alternated between effusive and explosive activity on a $\sim 30-50$ yr time scale, with the largest sub-Plinian to Plinian events every $\sim 330$ years [Turner et al. 2011; Damaschke et al. 2017].

Taranaki volcanism over the past 1000 years has been characterised by repeated mass flows related to the growth and collapse of summit lava domes [Platz 2007; Platz et al. 2012; Lerner et al. 2019]. This millennial sequence is defined as the Maero Eruptive Period (MEP) and includes 11 distinct eruptive episodes, each containing one or more eruptive events. These events comprise a mix of eruptive styles, including those interpreted to be simple dome collapses (e.g. Puniho, Pyramid), rapid, repeated dome collapse (e.g. Waiweranui/ Turehu, Tahurangi), directed blasts (e.g. Newall), and large column-generating eruptions (e.g. Burrell, Te Popo) [Platz 2007; Lerner et al. in review]. As well as the fan of these deposits on the northwestern flanks of the volcano, associated ash fall and surge deposits occur to the east [Platz 2007; Torres-Orozco et al. 2018] (Figure 2). There were also two column-generating subPlinian eruptions during this time, leading to more extensive PDC and fall deposits on the eastern flanks [Platz 2007; Torres-Orozco et al. 2017]. Taranaki's most recent eruption took place between 1780 and $1800 \mathrm{AD}$, when the partial collapse of the present summit dome generated a series of small, short-runout BAFs that deposited into northwestern river catchments [Platz et al. 2012; Lerner et al. 2019].

The sequence of Maero Formation deposits on the 


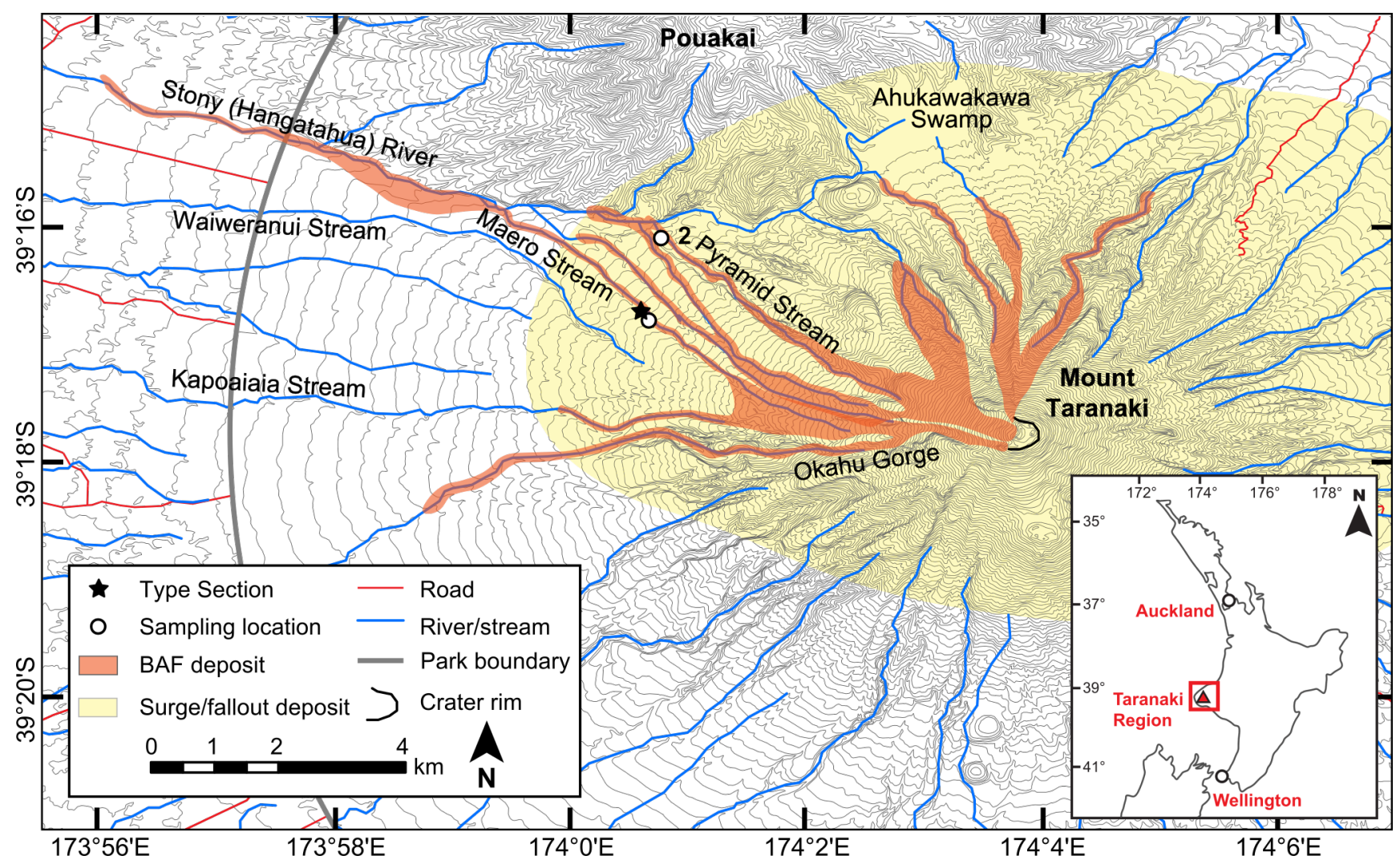

Figure 2: Map showing distribution of the Maero Formation-differentiated into the BAF and surge/fall deposits-in the region surrounding Mt. Taranaki. Location of type section and supplemental sampling sites are also noted. Inset shows location of Taranaki on the North Island of New Zealand.

volcano's northwestern flanks have been mapped as BAF units and debris flow deposits [Neall 1979; Platz 2007; Lerner et al. 2019]. Several deposits contain charcoal, used for radiocarbon dating [Neall 1979; Platz 2007], but much of it is not sufficiently coherent to thinsection. Throughout the deposit between $\sim 2$ and up to $15 \mathrm{~km}$ from source, deposits contain large clasts suitable for paleomagnetic sampling, particularly in medial reaches from $4-8 \mathrm{~km}$.

\section{Paleomagnetic estimation of emplace- MENT TEMPERATURE}

The coherence of paleomagnetic remanence directions between clasts in a deposit has been established as an effective technique for distinguishing volcanic deposits emplaced at temperatures over $\sim 500^{\circ} \mathrm{C}$ from those laid down at ambient temperature (or otherwise re-worked by slope processes) [Hoblitt and Kellogg 1979; Uehara et al. 2015]. Further, palaeomagnetic measurements can also be used to more precisely determine the emplacement temperature $\left(T_{e}\right)$ of a pyroclastic deposit emplaced between ambient temperature and the Curie temperature $\left(T_{c}\right)$ of its constituent ferrimagnetic minerals (usually between $500-600^{\circ} \mathrm{C}$ ) [Kent et al. 1981; Paterson et al. 2010].

Progressive thermal demagnetization separates the components of remanent magnetization carried in different intervals of the (un)blocking temperature spectrum of a sample. As a result, when thermally demagnetised, clasts taken from volcanic deposits will reveal one or more components of remanent magnetization acquired from the ambient magnetic field during cooling. The directions of these components from a clast are compared with those of the other clasts from the same site using a statistical randomness test [Watson 1956], with three scenarios possible depending on the conditions of emplacement:

1. Deposit emplaced above the Curie temperature: all clasts have cooled from above Curie temperature after emplacement, resulting in all clasts carrying a thermoremanent magnetization (TRM) throughout the whole blocking temperature spectrum that is aligned with the field at the time of cooling.

2. Deposit emplaced at ambient temperature: all clasts have cooled from above Curie temperature previously in a different location (or during transport). The physical randomisation of clasts associated with transport and emplacement results in a randomisation of the paleomagnetic directions, resulting in no inter-clast alignment of TRM.

3. Deposit emplaced at an intermediate temperature, $T_{e}$, below $T_{c}$ : clasts cool to $T_{e}$ before emplacement, 
resulting in a high blocking temperature component of TRM which is randomised along with the physical randomisation of the clasts during transport. After deposition, all clasts cool together in the same field, resulting in a low blocking temperature component of TRM aligned with the ambient field. In this instance, a more precise emplacement temperature can be determined by ascertaining the temperature which separates the random high blocking temperature component from the coherent low blocking temperature component.

Analysis of clasts in a volcanic deposit will result in a range of emplacement temperature estimates for different clasts. The lowest temperature of sampled clasts is generally considered the best estimate of the deposit's overall temperature at the time of emplacement [Bardot and McClelland 2000; Paterson et al. 2010].

This method has been frequently applied to volcanic deposits from single eruptive events or periods [e.g. Paterson et al. 2010; Uehara et al. 2015; Turner et al. 2018] in situations in which the age relationships of the deposits were not significant to the study. Here, these paleomagnetic methods were applied to multiple flow units of the Maero Formation representing several eruptive episodes over $\sim 1000$ years in order to better understand the types of volcanic hazards presented during Mt. Taranaki's most recent volcanic period. We attempted to differentiate high-temperature BAF units from other mass-flow deposits and waterborne lahar/debris flow deposits. Comparison of field data with paleomagnetic results revealed the type of mass flows most commonly seen at Taranaki over the past 1000 years and provides an understanding of the reliability of sedimentological analysis of outcrops for inferring emplacement temperatures.

\section{SAMPLING SCHEME AND METHODS}

Outcrops of the Maero Formation were described and photographed, concentrating on grainsize, texture, and lithology. Deposition units representing distinct stratigraphic events were analysed individually, with unit boundaries identified by the presence of paleosols, weathering horizons or widespread erosional contacts. In this study, deposits from seven episodes of the MEP were analysed: Te Popo (P1), Newall (M8), Waiweranui (M1, M2), Turehu (M2), Puniho (M3), Tahurangi (M5, M6), and Pyramid [Lerner et al. 2019] (Table 1).

Units were sampled along the Maero stream, where the current type section of the Maero Formation is located, near to past type sections damaged by erosion [Neall 1979; Platz 2007; Lerner et al. 2019] (Figure 3). This location covers as much of the Maero Formation as possible and stratigraphic relationships are clear. Additional outcrops were sampled elsewhere along the banks of the Maero stream and the nearby Stony River to complete the sequence. For each of the seven sites we sampled, marked, and oriented 8-12 clasts. The presence of charcoal was noted, and it was sampled for radiocarbon dating in companion studies.

One paleomagnetic specimen was drilled from each oriented clast and subjected to progressive thermal demagnetization in the Geomagnetism Laboratory at the Victoria University of Wellington using a Magnetic Measurements Ltd thermal demagnetiser. Paleomagnetic measurements were taken after each demagnetization step with an Agico JR-6A spinner magnetometer. Principal component analysis and statistical calculations of paleomagnetic data were carried out using Remasoft software [Chadima and Hrouda 2006], while outlier discordancy analysis and randomness testing were carried out using PmagTool [Mark W. Hounslow, CEMP, Lancaster, UK]. Low field magnetic susceptibility was measured after each demagnetization step using a Bartington MS2 susceptibility meter to monitor for thermally induced alteration to the magnetic mineralogy. Temperature dependence of magnetic susceptibility curves were measured on crushed 3-5 g samples with a Bartington MS2 magnetic susceptibility system and furnace.

\section{Results}

Charcoal was found in the field at sites M8, M1, and M3. Previous studies of the Maero Formation have recorded the presence of charcoal in at least some exposures within most recognised events during the Maero Eruptive Period [Platz 2007; Turner et al. 2008; Damaschke et al. 2017]. Charcoal is most prominent in the Waiweranui unit and includes large charcoalised logs. Gas elutriation pipes were found in a few locations, primarily located directly above charcoalised logs in the Waiweranui unit.

Deposits in the sequence mostly showed similar characteristics in outcrop (massive/unbedded or with a weak horizontal fabric, poorly sorted, matrix supported with sub-angular clasts typically of grey andesite set in an ash grade matrix) with some variation that allowed distinction between units. The oldest unit, the Te Popo (P1), is approximately $1.7 \mathrm{~m}$ thick and shows dominantly grey angular blocks concentrated in the upper part of the unit, grading downwards into a matrixsupported middle section containing some lapilli to block-size clasts, which overlies a clast-supported base with lapilli to block-size clasts. The Newall (M8), shows mainly matrix-supported deposits of thicknesses up to $\sim 5 \mathrm{~m}$, but is distinguished by its large component of orange/reddish hydrothermally altered clasts, which are rare in other Maero Formation deposits. The Waiweranui and Turehu units (M2, M3) overly the Newall, consist of at least 3 separate flow units up to $9 \mathrm{~m}$ in total thickness. The thickest, basal unit is matrix-supported with lapilli to block clasts and topped by a lapillibearing fine lapilli tuff. The top unit, separated from 
Table 1 - Site locations and Unit Dates of Emplacement.

\begin{tabular}{rcccc}
\hline Site & Episode & Lat & Long & Date of Emplacement (AD $)^{*}$ \\
\hline & & & & \\
P1 & Te Popo & $-39^{\circ} 16^{\prime} 06.9^{\prime \prime}$ & $174^{\circ} 00^{\prime} 37.4^{\prime \prime}$ & $1131 \pm 51$ \\
M8 & Newall & $-39^{\circ} 16^{\prime} 49.1^{\prime \prime}$ & $174^{\circ} 00^{\prime} 40.5^{\prime \prime}$ & $1363 \pm 34$ \\
M1 & Waiweranui & $-39^{\circ} 16^{\prime} 43.8^{\prime \prime}$ & $174^{\circ} 00^{\prime} 37.0^{\prime \prime}$ & $1461 \pm 8$ \\
M2 & Waiweranui/Turehu & $-39^{\circ} 16^{\prime} 43.8^{\prime \prime}$ & $174^{\circ} 00^{\prime} 37.0^{\prime \prime}$ & $1472 \pm 13$ \\
M3 & Puniho & $-39^{\circ} 16^{\prime} 43.8^{\prime \prime}$ & $174^{\circ} 00^{\prime} 37.0^{\prime \prime}$ & $1550 \pm 38$ \\
M5 & Tahurangi & $-39^{\circ} 16^{\prime} 43.8^{\prime \prime}$ & $174^{\circ} 00^{\prime} 37.0^{\prime \prime}$ & $1755 \pm 16$ \\
M6 & Tahurangi & $-39^{\circ} 16^{\prime} 43.8^{\prime \prime}$ & $174^{\circ} 00^{\prime} 37.0^{\prime \prime}$ & $1755 \pm 16$ \\
& Pyramid $^{+}$ & $-39^{\circ} 17^{\prime} 36.6^{\prime \prime}$ & $174^{\circ} 02^{\prime} 05.3^{\prime \prime}$ & $1790 \pm 6$ \\
\hline
\end{tabular}

${ }^{*}$ Date of emplacement of units from statistical modelling of Lerner et al. [in review]

${ }^{\dagger}$ Pyramid samples from Lerner et al. [2019]

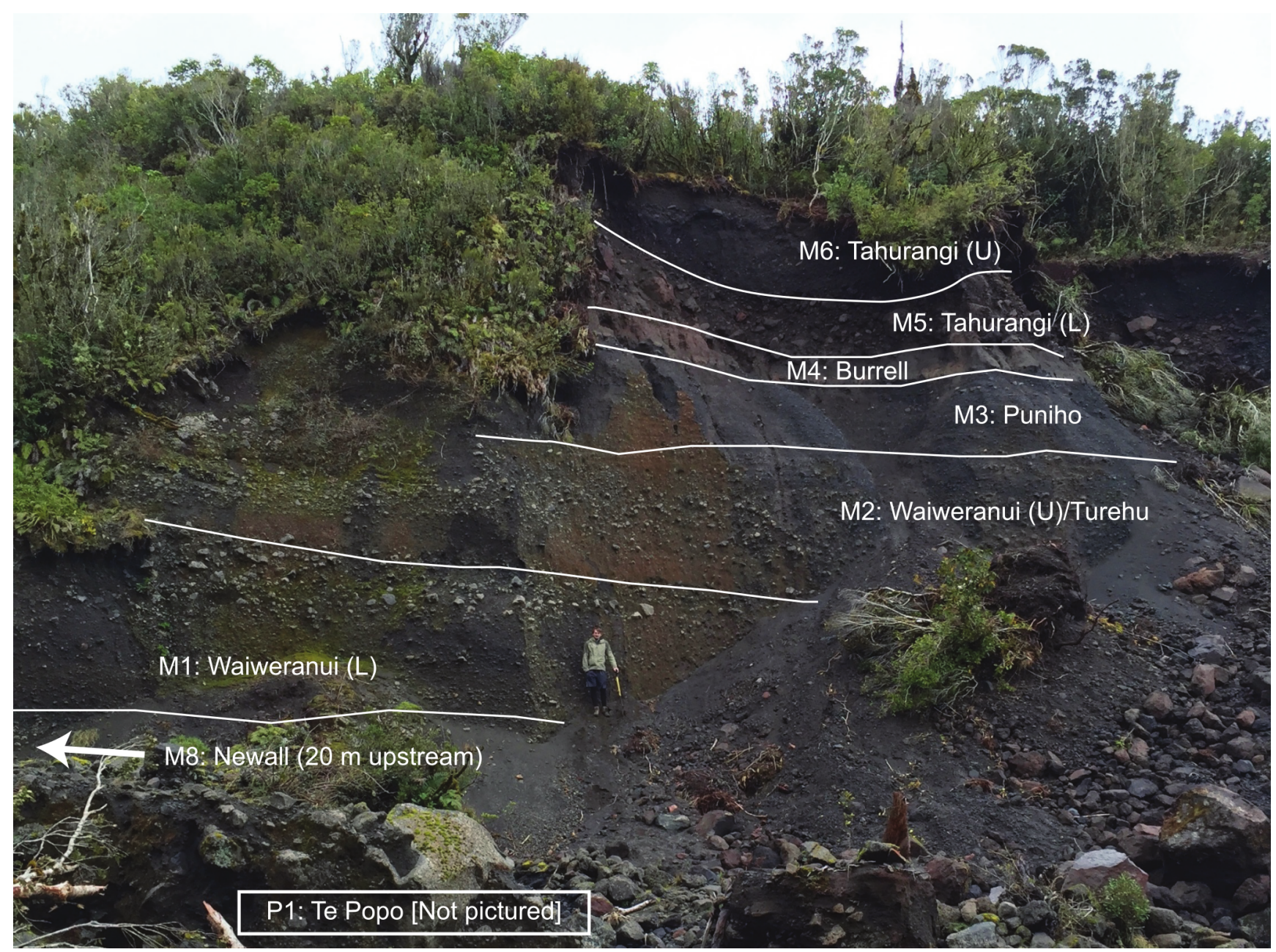

Figure 3: Annotated photograph of the type section of the Maero Formation in the Maero stream, showing units sampled in this study. Site M8 (Newall unit) was sampled $20 \mathrm{~m}$ upstream on the same river bank as this photo. P1 (Te Popo) is not pictured; it was sampled at a separate location in the Pyramid stream.

those below by a weak soil, is a $<40 \mathrm{~cm}$ weakly stratified deposit. These units consist almost exclusively of grey to black andesite. Above the Turehu, the Puniho unit (M3) is an up to $1 \mathrm{~m}$-thick, matrix supported deposit containing primarily lapilli-sized clasts. The Burrell unit (M4, present in the type section but not sam- pled for this study), was emplaced during a phase of an eruption that eventually produced a sub-Plinian eruption column and is represented in the type section as a $<70 \mathrm{~cm}$-thick coarse brown fine-lapilli tuff that did not contain enough large clasts for paleomagnetic study. The Tahurangi (M5, M6) contains at least two subunits: 

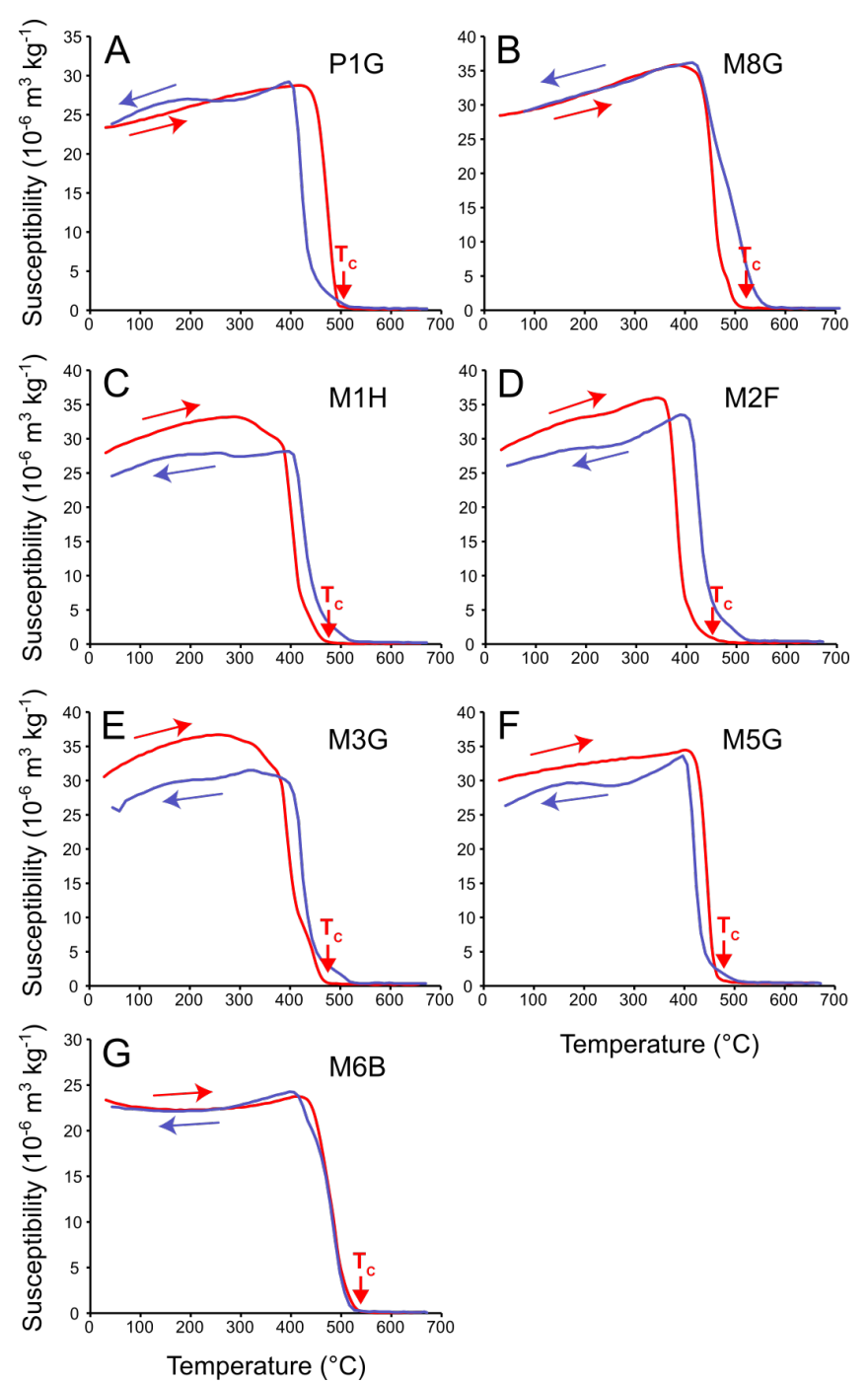

Figure 4: Temperature dependence of magnetic susceptibility of Maero block-and-ash flow deposit clast samples. Curves from $[A]$ to $[G]$ represent units of decreasing age within the sequence. Red line represents heating, blue line represents cooling. Curie temperature of magnetic minerals are shown by the red arrows.

the lower is an up to $3 \mathrm{~m}$-thick, coarse, matrix-poor breccia containing primarily block-sized clasts; while the upper part is a $50 \mathrm{~cm}$-thick red to brown ashrich deposit containing primarily lapilli-sized clasts. The Tahurangi unit contains an unusually high proportion of reddish-oxidised lava blocks and lapilli, only seen rarely in other Maero Formation deposits. The youngest Maero episode, represented by the Pyramid unit [Lerner et al. 2019], is found only in areas closer to the volcano $(\sim 2-5 \mathrm{~km})$ as an up to $6 \mathrm{~m}$-thick clastsupported to matrix supported, breccia deposit showing weak horizontal fabric and clast trains in places. Each of the units show matching lithologies for both their block and lapilli clasts and matrix ash grades, reflecting the differences between units as described above.
The Waiweranui, Turehu, and Puniho units (M1, M2, and M3) are distinguishable as independent events due to thin soil horizons occurring between them in several (but not all) locations, as well as a set of crossbedded ash and lapilli tuff beds (consistent with surge deposits). The most distinctive units recognised by lithological properties, are the Newall unit (common orange, hydrothermally altered clasts); the Burrell unit (pumice clasts); and the Tahurangi unit (dark-red oxidised clasts).

The bulk magnetic susceptibility of Maero Formation clasts varies between 39.7 and $69.3 \times 10^{-3}$ SI (Table 2). Results of the temperature-dependence of susceptibility experiments are shown in Figure 4. All plots are essentially reversible, showing a single sharp drop corresponding to Curie temperatures in the range of $470-520^{\circ} \mathrm{C}$. This is consistent with a titanomagnetite $\mathrm{Fe}_{3-x} \mathrm{Ti}_{x} \mathrm{O}_{4}$ with $x \approx 0.20-0.15$, compatible with compositions previously found in lavas at Mt. Taranaki [Damaschke et al. 2017], but slightly higher in titanium concentration than titanomagnetites found in ca. 3000 year-old pyroclastic density current deposits on the NE flanks by Turner et al. [2018]. The susceptibilities and Curie temperatures found in this study also correspond well with those found in material from the most recent episode of the Maero Eruptive Period (the Pyramid episode) [Lerner et al. 2019].

The intensity of the natural remanent magnetization (NRM) of Maero sites ranges between 2.3 and 11.4 $\mathrm{A} / \mathrm{m}$ (Table 2). In most samples the main phase of the demagnetization starts around $300-450^{\circ} \mathrm{C}$ with only a small gradual decrease in intensity taking place at lower temperatures in some samples (Figure 5). This is consistent with demagnetization behaviour found in material from Taranaki's most recent block-and-ash flow deposit [Lerner et al. 2019]. Vector component diagrams (Figure 5) show that the characteristic component of TRM (ChRM) is well defined up to the Curie temperature. Progressive thermal demagnetization, after cleaning a low temperature viscous remanent magnetization (VRM), showed a single component of remanence in all Maero Formation samples. This characteristic component of remanence (ChRM) from each sample was used to determine a site mean paleomagnetic direction and a lower temperature limit of emplacement is obtained from the maximum unblocking temperature (Table 2, Figure 6).

Measured clasts at six of the seven sites show consistent ChRM directions up to the maximum laboratoryobserved unblocking temperatures (Figure 6A-D, F$\mathrm{G})$. This indicates minimum emplacement temperatures between 480 and $520^{\circ} \mathrm{C}$ for material from those sites (Figure $5 \mathrm{~A}-\mathrm{D}, \mathrm{F}-\mathrm{G}$ ). ChRM of specimens at site M3 were randomly aligned (Figure 6E) indicating emplacement below the lowest observed unblocking temperature-about $300^{\circ} \mathrm{C}$. Samples with outlying ChRM directions were classified and omitted from sample mean variation according to Fisher statistics us- 
Table 2 - Paleomagnetic results.

\begin{tabular}{rlccccccccc}
\hline Site & Episode & $\begin{array}{c}\text { Bulk Susc } \\
\left(\times 10^{-3} \text { SI }\right)\end{array}$ & $\begin{array}{c}\text { NRM } \\
\text { Intensity } \\
(\mathrm{A} / \mathrm{m})\end{array}$ & $n / N$ & $\operatorname{Dec}\left({ }^{\circ}\right)$ & Inc $\left(^{\circ}\right)$ & $R$ & $k$ & $\alpha 95\left(^{\circ}\right)$ & $T_{e}\left({ }^{\circ} \mathrm{C}\right)$ \\
\hline P1 & Te Popo & $43 \pm 10$ & $2.4 \pm 1.2$ & $8 / 8$ & 7.2 & -69.7 & 7.89 & 66.31 & 6.9 & $>500$ \\
M8 & Newall & $69 \pm 30$ & $3.0 \pm 2.2$ & $5 / 7$ & 0.6 & -62.6 & 4.96 & 90.68 & 8.1 & $>500$ \\
M1 & Waiweranui & $53 \pm 10$ & $4.0 \pm 3.6$ & $7 / 8$ & 350.7 & -67.2 & 6.76 & 24.77 & 12.4 & $>480$ \\
M2 & Waiweranui/ & $61 \pm 20$ & $11.4 \pm 4.4$ & $9 / 9$ & 347.2 & -58.2 & 8.19 & 9.87 & 17.2 & $>480$ \\
& Turehu & & & & & & & & & \\
M3 & Puniho & $55 \pm 5$ & $9.8 \pm 4.3$ & $10 / 10$ & $\mathrm{n} / \mathrm{a}$ & $\mathrm{n} / \mathrm{a}$ & 2.63 & 1.22 & $\mathrm{n} / \mathrm{a}$ & $\mathrm{Cold}$ \\
M5 & Tahurangi & $40 \pm 10$ & $6.0 \pm 4.5$ & $8 / 8$ & 6.8 & -67.6 & 7.73 & 25.89 & 11.1 & $>490$ \\
M6 & Tahurangi & $44 \pm 8$ & $3.5 \pm 3.5$ & $8 / 9$ & 347.7 & -62.1 & 7.94 & 118.28 & 5.1 & $>520$ \\
& Pyramid & $57 \pm 3$ & $6.0 \pm 6.0$ & $13 / 16$ & 16.8 & -38.2 & 11.85 & 72.21 & 5.1 & $>200$ \\
\hline
\end{tabular}

Site = Independent grouping of clasts from a single flow unit for the calculation of a mean;

Bulk Susc $=$ mean bulk magnetic susceptibility of specimens from a site with $1 \sigma$;

NRM intensity = mean natural remanent magnetization of specimens at a site prior to demagnetization with $1 \sigma$;

$n / N=$ specimens included in mean calculation/specimens measured;

Dec $=$ declination;

Inc $=$ inclination:

$R=$ length of sum of unit vectors;

$k=$ estimate of the precision parameter;

$\alpha 95=$ semi-angle cone of $95 \%$ confidence in mean direction;

$T_{e}=$ emplacement temperature estimate.

${ }^{\star}$ from Lerner et al. [2019]

ing the PmagTool software [Mark W. Hounslow, CEMP, Lancaster, UK].

\section{Discussion}

The overall directions from the Maero Formation deposits are consistent with directions seen in the geomagnetic field between $1000 \mathrm{BP}$ and the present day. When compared with the paleosecular variation curve for New Zealand over the past 1000 years [NZPSV1k: Turner et al. 2015], the paleodirections found at most sites in this study fit within the range of expected declination and inclination values, with the exception of the shallower Pyramid (D: $16.8^{\circ}$, I: $-38.2^{\circ}$ ). The Maero paleodirections range from a declination of $347.2^{\circ}$ to $7.2^{\circ}$ and Inclination $-58.7^{\circ}$ to $-67.6^{\circ}$. In the last 1000 years, declination has swung from $\sim 350^{\circ}$ to $20^{\circ}$ and inclination from $\sim-55^{\circ}$ to $-65^{\circ}$ [Turner et al. 2015].

The paleomagnetic emplacement temperature estimates in this study largely agree with the sedimentary indicators of hot-emplacement (e.g. charcoal, oxidised deposit top, associated pyroclastic surge deposits) and features associated with BAFs (near-homogenous lithology, similar lithology of clasts and matrix, fineash units below or above) confirming that the 1000 year record of the Maero Formation is primarily composed of deposits of hot $\left(>500^{\circ} \mathrm{C}\right)$ block-and-ash flow deposits. The one exception is the Puniho unit (M3) site sampled here, with paleomagnetic evidence for a cold emplacement. The Puniho deposit contains charcoal, and was almost identical in appearance to the Waiweranui units (M1 and M2) (Figure 7). This shows how field characteristics are not always reliable for interpretation. The result could be due to (1) a localised site-specific redistribution or disturbance of a primary deposit (e.g., by localised slope collapse); (2) that the Puniho PDCs had a shorter runout than the others, before being reworked and redeposited by lahars; or (3) that the Puniho deposits were emplaced by rock falls and granular flows produced by collapses of an already cooled lava dome. This third option best explains the combination of sedimentary features and the paleomagnetic results. Different temperatures of dome-collapse BAFs were also noticed in the latest Mt. Taranaki eruption, depending on whether materials collapsed from the carapace or inner parts of the dome [Lerner et al. 2019], but cold-dome collapses have also been postulated before during the Maero eruptive period [Neall 1979; Platz et al. 2012].

Debris flow or colluvial deposits reworked directly from BAF deposits and rockfall deposits from cold domes may show similar characteristics to the hotemplaced ones in outcrop. In this case, techniques such as charcoal reflectance would be misleading, because it is inherited from a preceding deposition event. By contrast, the paleomagnetic alignment of clasts in a high temperature deposit is disrupted by any remobilization, making it useful for determining hot vs. cold emplacement. However, the method cannot distinguish 
A

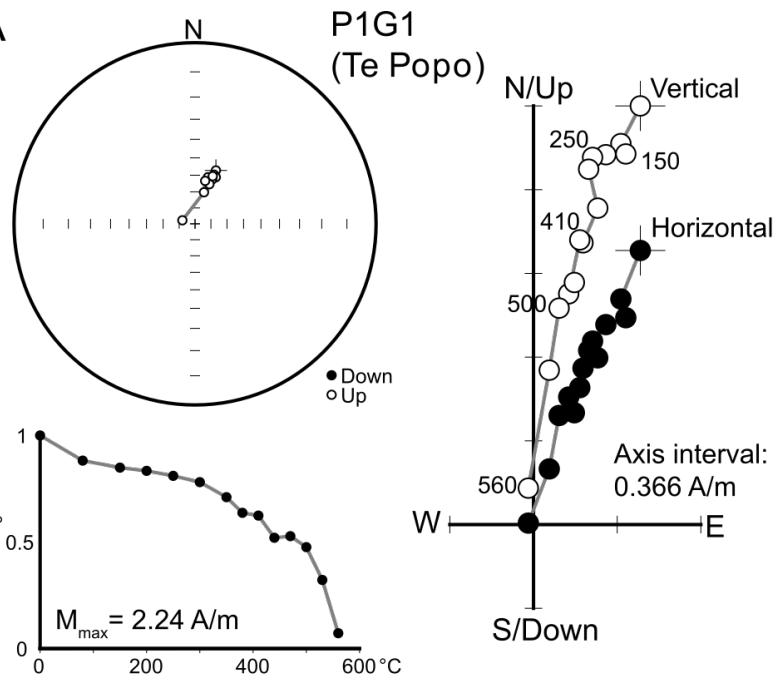

C

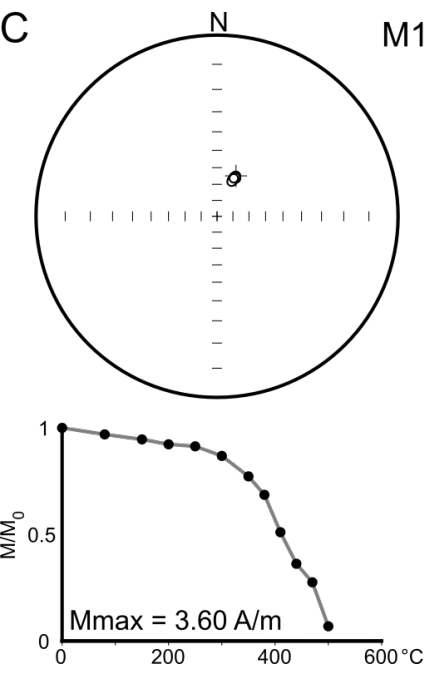

M1A1 (Waiweranui)

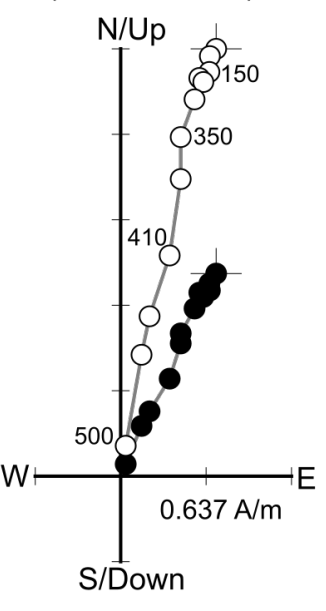

B
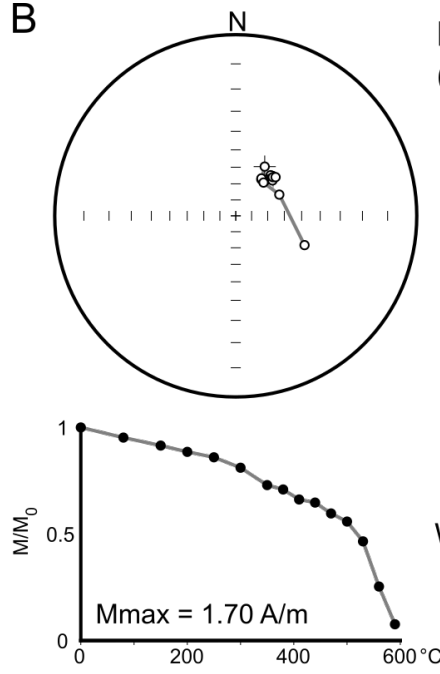

M8F1

(Newall)

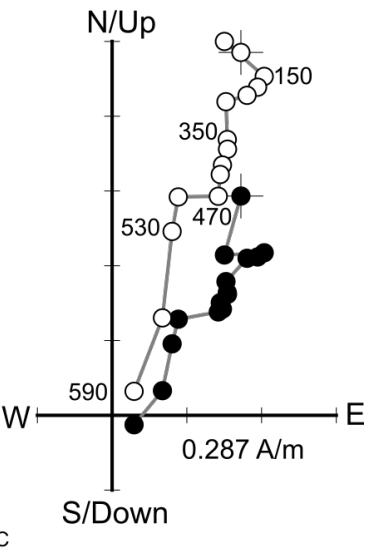

D

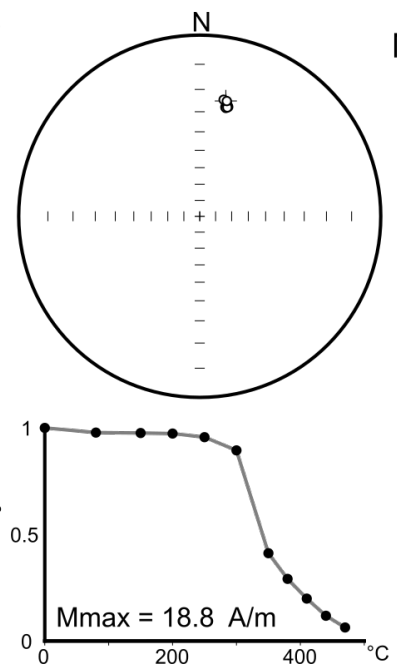

M2E2 (Waiweranui)

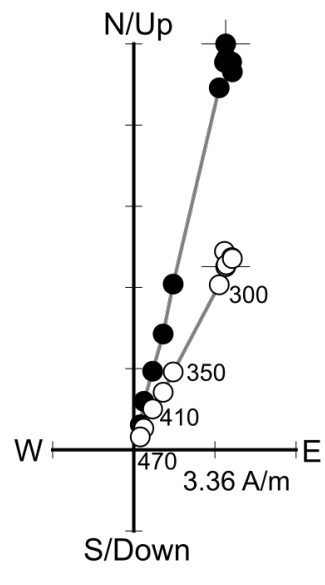

Figure 5: Progressive thermal demagnetization data for specimens from Maero deposits. [A] to [G] represent samples from sites of decreasing age within the sequence (unit name specified for each specimen). Diagrams show decrease of normalised remanent intensity with demagnetization $\left(M / M_{0}=\right.$ magnetization at demagnetization step/initial magnetization), equal angle plot of remanent direction (open circles represent projections on the upper hemisphere, closed circles represent projections on the lower hemisphere), and vector component plot showing horizontal and vertical components of remanence (solid and open dots, respectively; number labels represent thermal demagnetization temperature steps in ${ }^{\circ} \mathrm{C}$ ). [Continued on next page.]

between a deposit that originated at ambient temperature and one reworked from a high-temperature parent. For example, in this study case, it is impossible to tell with absolute certainty whether the Puniho unit (M3) was a locally reworked BAF unit, or whether it formed by collapse of a cold lava dome.

The high-temperature results for most of the units in this study indicate that at medial distances (5-10 $\mathrm{km}$ from the source), BAFs were produced during several eruption episodes of the Maero Eruptive Period, by collapse of very hot lava domes. This indicates that dome effusion rates must have been high and that many successive domes were formed over periods where thin soils indicate only short breaks between episodes. There is a lack of debris flow deposits at this range from the volcano (yet many downstream), show- ing that up to $\sim 10 \mathrm{~km}$ is the main deceleration zone for BAFs from conditions near the present configuration of Mt. Taranaki. Further BAFs may have been emplaced in winter onto snow and ice, which could have meant that deposition bypassed the $5-10 \mathrm{~km}$ range, but debris flows are emplaced farther from source [c.f. Nevado del Ruiz: Pierson et al. 1990].

The exceptionally high rainfall inside Egmont National Park (>7000 mm/year) causes deep erosion and common flood/landslide and sediment re-distribution events. This has formed mainly immature, deep, boxcut gullies through the BAF deposit fans over the last 200 years. Rapid downcutting occurs in this area during decadal very large rainstorms or cyclones. Preservation of some primary BAF deposits is probably due to their high internal porosity and permeability under 


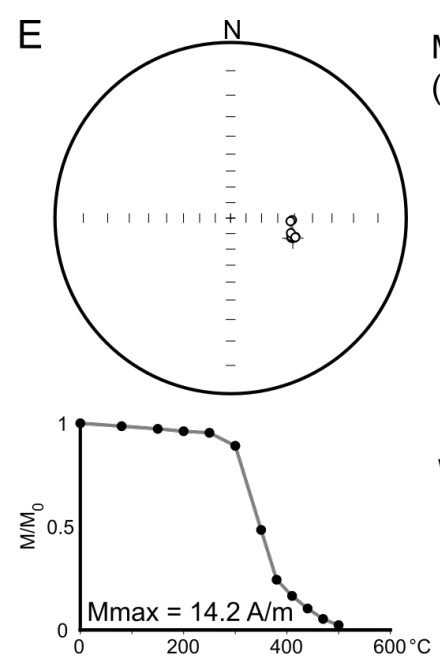

M3B1

(Puniho)

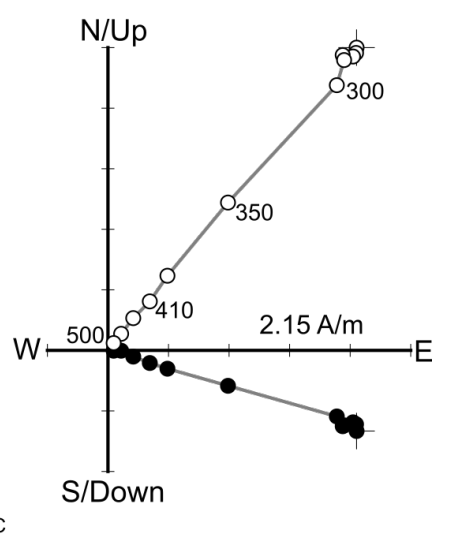

$\mathrm{F}$
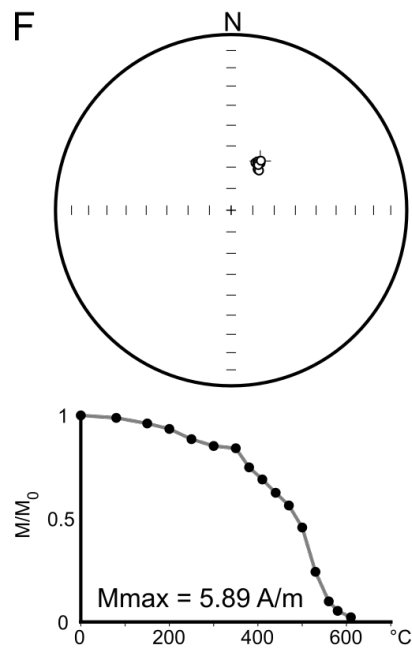

M5C1 (Tahurangi)
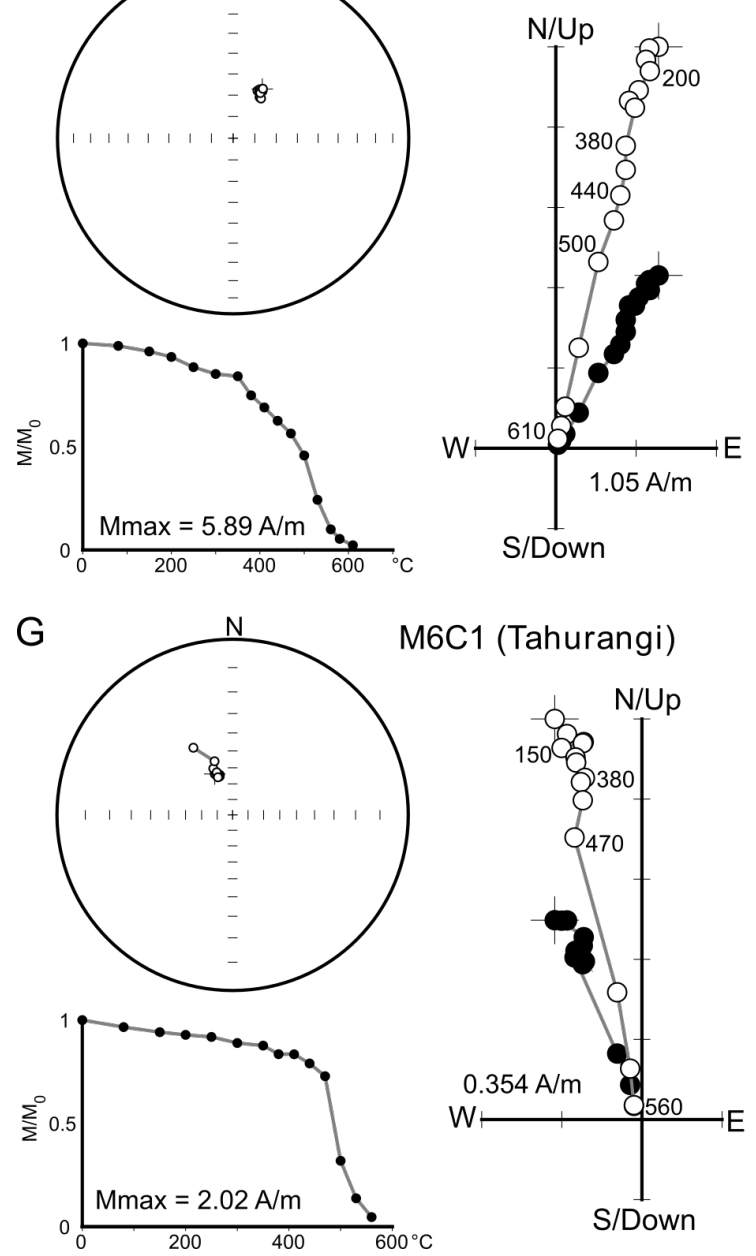

Figure 5: [cont.]

most rainfall events [Lavigne et al. 2000].

The high $\left(>500^{\circ} \mathrm{C}\right)$ emplacement temperature of the majority of deposits of the Maero Formation indicates repeated growth and collapse of fresh hot lava domes. Based on the cooling rates calculated by Lerner et al. [2019], the center of a Taranaki summit dome should take 30-50 years to cool below $500^{\circ} \mathrm{C}$ (with the outer carapace taking $<10$ years). This shows that most of Taranaki's largest dome collapses must have occurred soon after dome emplacement or during it. Collapses probably also involved large proportions of the dome, with deep-seated collapse. Intervals of rapid and repeated dome emplacement and collapse, coupled with multiple high temperature BAFs appears to have typified a long stretch of activity within the Maero Eruptive period, a $\sim 110 \mathrm{yr}$-long period between the Newall and the Turehu.

\section{Conclusions}

Paleomagnetic results and field studies show that the majority of the pyroclastic deposits of the past 1000 years at Mt. Taranaki were emplaced from high temperature $\left(>500^{\circ} \mathrm{C}\right)$ block-and-ash flows caused by deepseated collapses of still-hot lava domes. These collapses typically occurred during or shortly after dome emplacement (within about 30 years), sometimes in rapid succession. This activity type is thus highly likely in any future scenario for Mt. Taranaki eruptions.

The similarity of sedimentary and lithology features between a cold-emplaced rock avalanche, debris flow, or colluvial unit to the hot BAF deposits in this study shows that laboratory paleomagnetic testing is necessary to be absolutely sure of the emplacement conditions. Field granulometric and sedimentological evidence or even the presence of charcoal, may lead to misinterpretations, especially at greater distances from the volcano.

\section{Acknowledgements}

GL would like to thank AINSE Ltd for providing financial assistance (Award - PGRA) to enable work on this project and to the George Mason Charitable Trust for providing financial assistance towards fieldwork. SJC is supported by the Natural Hazards Research Platform Project "Quantifying exposure to specific and multiple volcanic hazards". The authors are grateful to Elisa Piipsa, Edgar Zorn, Manuela Tost, Mirja Heinrich, Christopher Schmidt, and Jie Wu for assistance with fieldwork. The authors would like to thank Davie Brown and an anonymous reviewer, along with Volcanica editor Rebecca Williams, for constructive comments that led to the improvement of the manuscript.

\section{Author contributions}

SJC, GMT, and GAL conceived the study. GAL performed all fieldwork, lab work, and data analysis with assistance from SJC and GMT. GAL wrote the original manuscript. All authors contributed to and edited the manuscript. 


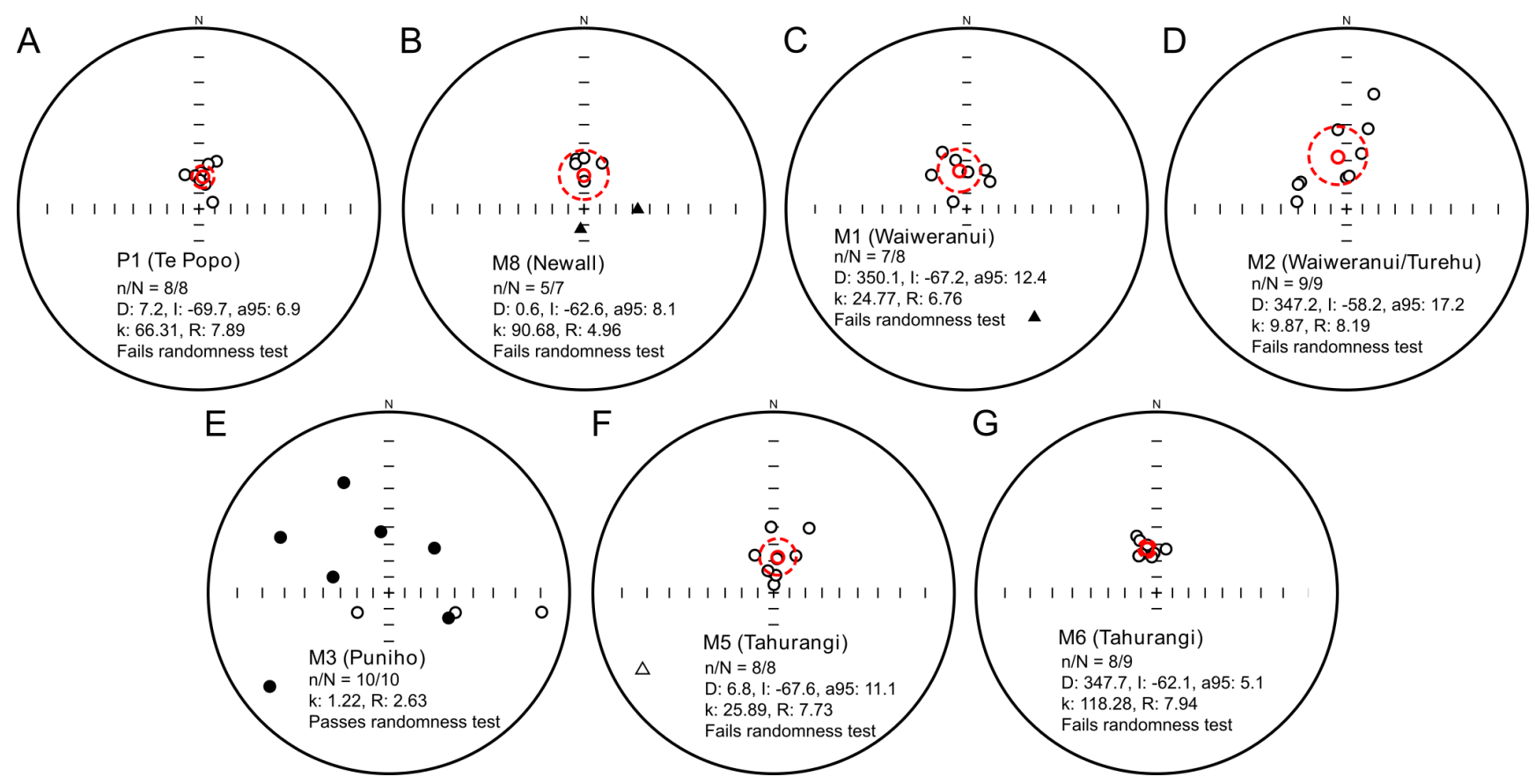

Figure 6: Equal angle projections showing directions of characteristic remanence for samples from Maero units. Open circles represent projections on the upper hemisphere, closed circles represent projections on the lower hemisphere. Open/closed triangles represent specimens classified as outliers according to Fisher statistics. Red circle $=$ estimated site mean direction. Red dashed ring around site mean $=95 \%$ confidence range. $\mathrm{D}=$ declination, $\mathrm{I}=$ inclination, $\alpha 95=$ semi-angle cone of $95 \%$ confidence in mean direction, $n / N=$ the ratio of the number of specimens used for the site analysis to the total number of specimens demagnetised, $R=$ length of sum of unit vectors, $k=$ estimate of the precision parameter [Fisher 1953]. Sites that fail a statistical randomness test [Watson 1956] show a preferred inter-clast alignment of remanence directions, interpreted to reflect post-emplacement magnetization.

\section{Data AVailability}

All data used in this study are presented in Table 2 and Figures 4,5 and 6 . The authors are happy to provide raw data upon request.

\section{Copyright Notice}

(C) The Author(s) 2019. This article is distributed under the terms of the Creative Commons Attribution 4.0 International License, which permits unrestricted use, distribution, and reproduction in any medium, provided you give appropriate credit to the original author(s) and the source, provide a link to the Creative Commons license, and indicate if changes were made.

\section{REFERENCES}

Andreastuti, S., E. Paripurno, H. Gunawan, A. Budianto, D. Syahbana, and J. Pallister (2017). "Character of community response to volcanic crises at Sinabung and Kelud volcanoes". Journal of Volcanology and Geothermal Research. DoI: 10.1016 / j . jvolgeores.2017.01.022.
Bardot, L. and E. McClelland (2000). "The reliability of emplacement temperature estimates using palaeomagnetic methods: a case study from Santorini, Greece". Geophysical Journal International 143.1, pp. 39-51. Dor: 10.1046/ j . 1365-246x. 2000. 00186.x.

Bowles, J. A., D. M. Gerzich, and M. J. Jackson (2018). "Assessing New and Old Methods in Paleomagnetic Paleothermometry: A Test Case at Mt. St. Helens, USA". Geochemistry, Geophysics, Geosystems 19.6, pp. 1714-1730. DoI: 10.1029/2018gc007435.

Brown, R. J. and G. D. M. Andrews (2015). "Deposits of Pyroclastic Density Currents". The Encyclopedia of Volcanoes. Elsevier, pp. 631-648. DoI: 10.1016/ b978-0-12-385938-9.00036-5.

Calder, E. S., R. Luckett, R. S. J. Sparks, and B. Voight (2002). "Mechanisms of lava dome instability and generation of rockfalls and pyroclastic flows at Soufrière Hills Volcano, Montserrat". Geological Society, London, Memoirs 21.1, pp. 173-190. DOI: 10 . 1144 /gsl . mem. 2002.021.01.08.

Chadima, M. and F. Hrouda (2006). "Remasoft 3.0 a user-friendly paleomagnetic data browser and analyzer". Travaux Géophysiques 27, pp. 20-21. 

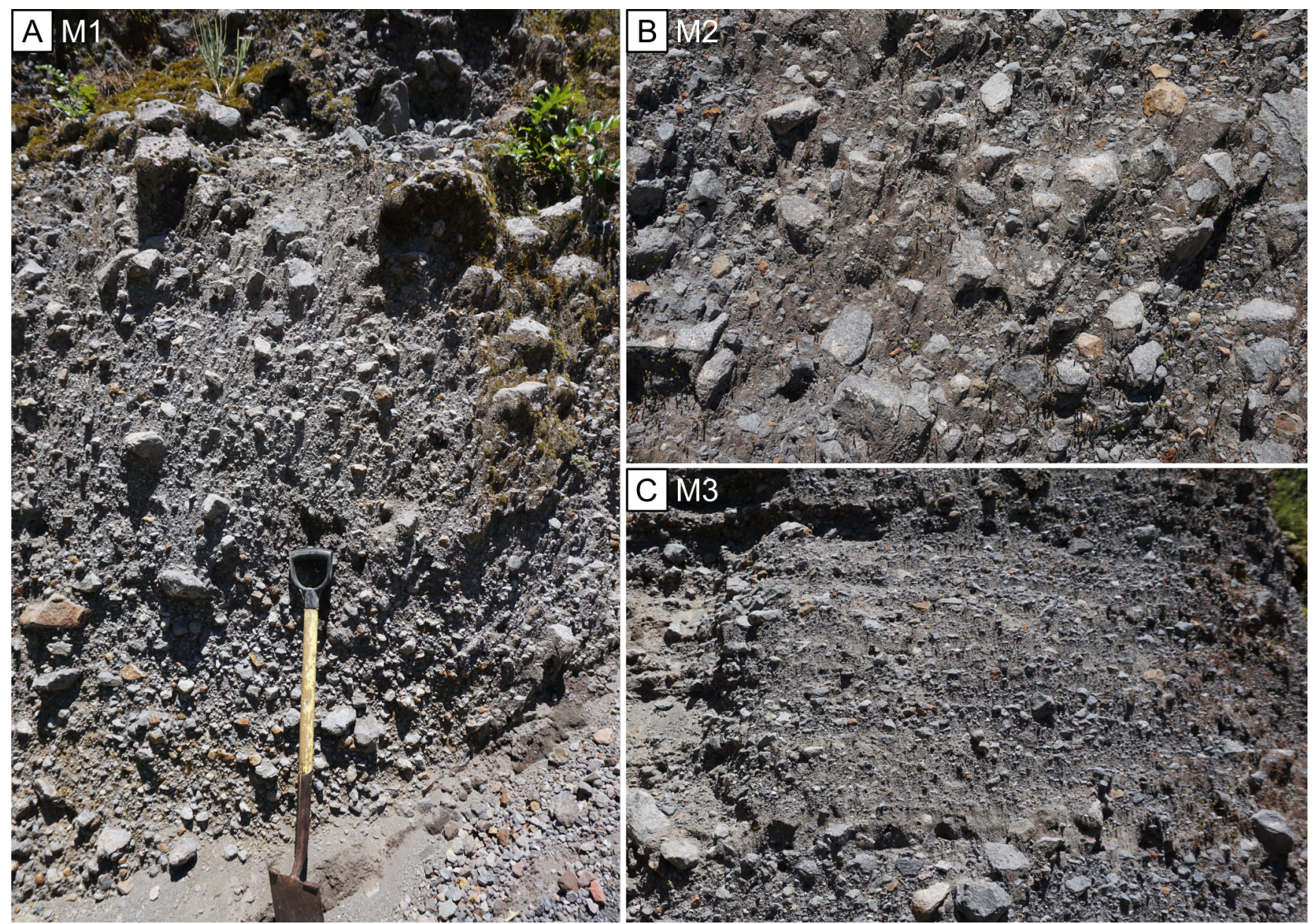

Figure 7: Comparison of sites M1 [A] and M2 [B] from the Waiweranui/Turehu unit deposited at temperatures above $480^{\circ} \mathrm{C}$ with site M3 [C] from the Puniho unit deposited at near ambient temperature. Similar characteristics are seen among all units, including matrix-support and color of matrix, and clast size, sorting, rounding, and color. The M3 deposit picture shows stronger horizontal fabric and clast trains than the other sites pictured, but these features are common in the hot-emplaced units also.

Charbonnier, S. and R. Gertisser (2008). "Field observations and surface characteristics of pristine blockand-ash flow deposits from the 2006 eruption of Merapi Volcano, Java, Indonesia". Journal of Volcanology and Geothermal Research 177.4, pp. 971-982. Dor: 10 . 1016/ j . jvolgeores.2008.07.008.

Cole, P. D., E. S. Calder, R. S. J. Sparks, A. B. Clarke, T. H. Druitt, S. R. Young, R. A. Herd, C. L. Harford, and G. E. Norton (2002). "Deposits from domecollapse and fountain-collapse pyroclastic flows at Soufrière Hills Volcano, Montserrat". Geological Society, London, Memoirs 21.1, pp. 231-262. Dor: 10 . 1144/gsl.mem. 2002.021.01.11.

Cronin, S. J., G. Lube, D. S. Dayudi, S. Sumarti, S. Subrandiyo, and Surono (2013). "Insights into the October-November 2010 Gunung Merapi eruption (Central Java, Indonesia) from the stratigraphy, volume and characteristics of its pyroclastic deposits". Journal of Volcanology and Geothermal Research 261, pp. 244-259. Dor: 10.1016/ j . jvolgeores. 2013.01 005.

Damaschke, M., S. J. Cronin, K. A. Holt, M. S. Bebbington, and A. G. Hogg (2017). "A 30, 000 yr high-precision eruption history for the andesitic Mt. Taranaki, North Island, New Zealand". Quaternary Research 87.01, pp. 1-23. DoI: 10.1017/ qua.2016.11.

Druitt, T. (1995). "Settling behaviour of concentrated dispersions and some volcanological applications". Journal of Volcanology and Geothermal Research 65.12, pp. 27-39. Dor: 10.1016/0377-0273 (94) 00090-4. Efford, J. T., R. J. Bylsma, B. D. Clarkson, A. Pittari, K. Mauriohooho, and V. G. Moon (2014). "Vegetation dieback as a proxy for temperature within a wet pyroclastic density current: A novel experiment and observations from the 6th of August 2012 Tongariro eruption". Journal of Volcanology and Geothermal Research 286, pp. 367-372. DoI: 10 . $1016 /$ j . jvolgeores.2014.05.016. 
Fisher, R. (1953). "Dispersion on a Sphere". Proceedings of the Royal Society A: Mathematical, Physical and Engineering Sciences 217.1130, pp. 295-305. Dor: 10. 1098/rspa. 1953.0064.

Fisher, R. V. and H.-U. Schmincke (2012). Pyroclastic rocks. Springer Science \& Business Media.

Hoblitt, R. P. and K. S. Kellogg (1979). "Emplacement temperatures of unsorted and unstratified deposits of volcanic rock debris as determined by paleomagnetic techniques". Geological Society of America Bulletin 90.7, p. 633. DoI: 10.1130/0016-7606(1979) $90<633$ : etouau $>2.0$. co;2.

Kent, D. V., D. Ninkovich, T. Pescatore, and S. R. J. Sparks (1981). "Palaeomagnetic determination of emplacement temperature of Vesuvius AD 79 pyroclastic deposits". Nature 290.5805, pp. 393-396. DoI: 10. 1038/290393a0.

Lavigne, F., J. Thouret, B. Voight, H. Suwa, and A. Sumaryono (2000). "Lahars at Merapi volcano, Central Java: an overview". Journal of Volcanology and Geothermal Research 100.1-4, pp. 423-456. Dor: 10 . 1016/s0377-0273(00)00150-5.

Lerner, G. A., S. J. Cronin, M. S. Bebbington, and T. Platz (in review). "The characteristics of a multiepisode volcanic period; the post-AD960 Maero eruptive period of Mt. Taranaki (New Zealand)". Bulletin of Volcanology.

Lerner, G. A., S. J. Cronin, G. M. Turner, and M. C. Rowe (2019). "Paleomagnetic determination of the age and properties of the 1780-1800 AD dome effusion/collapse episode of Mt. Taranaki, New Zealand". Bulletin of Volcanology 81.3. Dor: 10.1007/ s00445-019-1275-z.

Nakada, S., A. Zaennudin, M. Yoshimoto, F. Maeno, Y. Suzuki, N. Hokanishi, H. Sasaki, M. Iguchi, T. Ohkura, H. Gunawan, and H. Triastuty (2017). "Growth process of the lava dome/flow complex at Sinabung Volcano during 2013-2016". Journal of Volcanology and Geothermal Research. DoI: 10.1016/ j . jvolgeores.2017.06.012.

Neall, V. E. (1979). "Sheets P19, P20, \& P21 New Plymouth, Egmont, and Manaia". N.Z. Department of Scientific and Industrial Research.

Neall, V. E., I. E. Smith, and R. Stewart (1986). "History and petrology of the Taranaki volcanoes". Late Cenozoic Volcanism in New Zealand. Ed. by I. E. M. Smith. Wellington, New Zealand: Royal Society of New Zealand, pp. 251-263.

Paterson, G. A., A. P. Roberts, C. M. Niocaill, A. R. Muxworthy, L. Gurioli, J. G. Viramonté, C. Navarro, and S. Weider (2010). "Paleomagnetic determination of emplacement temperatures of pyroclastic deposits: an under-utilized tool". Bulletin of Volcanology 72.3, pp. 309-330. Dor: 10. 1007/s00445-009-0324-4.

Pierson, T. C., R. J. Janda, J.-C. Thouret, and C. A. Borrero (1990). "Perturbation and melting of snow and ice by the 13 November 1985 eruption of Nevado del
Ruiz, Colombia, and consequent mobilization, flow and deposition of lahars". Journal of Volcanology and Geothermal Research 41.1-4, pp. 17-66. DoI: 10.1016/ 0377-0273 ( 90 ) 90082-q.

Platz, T. (2007). "Understanding aspects of andesitic dome-forming eruptions through the last $1000 \mathrm{yrs}$ of volcanism at Mt. Taranaki, New Zealand: a dissertation presented in partial fulfilment of the requirements for the degree of Doctor of Philosophy in Earth Science, Massey University, Palmerston North, New Zealand". PhD thesis. Massey University.

Platz, T., S. J. Cronin, J. N. Procter, V. E. Neall, and S. F. Foley (2012). "Non-explosive, dome-forming eruptions at Mt. Taranaki, New Zealand". Geomorphology 136.1, pp. 15-30. Dor: 10.1016/ j . geomorph. 2011. 06.016.

Robertson, R. E. A., W. P. Aspinall, R. A. Herd, G. E. Norton, R. S. J. Sparks, and S. R. Young (2000). "The 1995-1998 eruption of the Soufriére Hills volcano, Montserrat, WI". Philosophical Transactions of the Royal Society of London. Series A: Mathematical, Physical and Engineering Sciences 358.1770. Ed. by P. Francis, J. Neuberg, and R. S. J. Sparks, pp. 1619-1637. DoI: $10.1098 /$ rsta.2000.0607.

Sawada, Y., Y. Sampei, M. Hyodo, T. Yagami, and M. Fukue (2000). "Estimation of emplacement temperatures of pyroclastic flows using $\mathrm{H} / \mathrm{C}$ ratios of carbonized wood". Journal of Volcanology and Geothermal Research 104.1-4, pp. 1-20. Dor: 10.1016/s03770273 ( 00 ) $00196-7$.

Schwarzkopf, L. M., H.-U. Schmincke, and S. J. Cronin (2005). "A conceptual model for block-and-ash flow basal avalanche transport and deposition, based on deposit architecture of 1998 and 1994 Merapi flows". Journal of Volcanology and Geothermal Research 139.12, pp. 117-134. DoI: 10.1016/ j . jvolgeores. 2004. 06.012.

Scott, A. C. and I. J. Glasspool (2005). "Charcoal reflectance as a proxy for the emplacement temperature of pyroclastic flow deposits". Geology 33.7, p. 589. Dor: $10.1130 / \mathrm{g} 21474.1$.

Tanaka, H., H. Hoshizumi, Y. Iwasaki, and H. Shibuya (2004). "Applications of paleomagnetism in the volcanic field: A case study of the Unzen Volcano, Japan". Earth, Planets and Space 56.7, pp. 635-647. DOI: $10.1186 / \mathrm{bf} 03352526$.

Thouret, J.-C. and F. Lavigne (2000). "Lahars: occurrence, deposits and behaviour of volcano-hydrologic flows". Volcaniclastic rocks from magma to sediments. Gordon and Breach Science Publishers. Ed. by H. Leyrit and C. Montenat. Gordon and Breach Science Publishers, pp. 151-174.

Torres-Orozco, R., S. J. Cronin, N. Pardo, and A. S. Palmer (2017). "New insights into Holocene eruption episodes from proximal deposit sequences at Mt. Taranaki (Egmont), New Zealand". Bulletin of Volcanology 79.1. DoI: 10.1007/s00445-016-1085-5. 
Torres-Orozco, R., S. J. Cronin, N. Pardo, and A. S. Palmer (2018). "Volcanic hazard scenarios for multiphase andesitic Plinian eruptions from lithostratigraphy: Insights into pyroclastic density current diversity at Mount Taranaki, New Zealand". GSA Bulletin 130.9-10, pp. 1645-1663. DoI: 10.1130/b31850.1.

Turner, G., J. Howarth, G. de Gelder, and S. Fitzsimons (2015). "A new high-resolution record of Holocene geomagnetic secular variation from New Zealand". Earth and Planetary Science Letters 430, pp. 296-307. Dor: 10.1016/ j .epsl.2015.08.021.

Turner, G. M., B. V. Alloway, B. J. Dixon, and C. B. Atkins (2018). "Thermal history of volcanic debris flow deposits on the eastern flanks of Mt. Taranaki, New Zealand: Implications for future hazards". Journal of Volcanology and Geothermal Research 353, pp. 55-67. DoI: 10.1016/ j . jvolgeores. 2018. 01.017.

Turner, M. B., S. J. Cronin, M. S. Bebbington, I. E. Smith, and R. B. Stewart (2011). "Integrating records of explosive and effusive activity from proximal and distal sequences: Mt. Taranaki, New Zealand". Quaternary International 246.1-2, pp. 364-373. Dor: $10.1016 / \mathrm{j}$. quaint.2011.07.006.
Turner, M. B., S. J. Cronin, I. E. Smith, R. B. Stewart, and V. E. Neall (2008). "Eruption episodes and magma recharge events in andesitic systems: Mt Taranaki, New Zealand". Journal of Volcanology and Geothermal Research 177.4, pp. 1063-1076. Dor: 10.1016/ j . jvolgeores.2008.08.001.

Uehara, D., R. Cas, C. Folkes, S. Takarada, H. Oda, and M. Porreca (2015). "Using thermal remanent magnetisation (TRM) to distinguish block and ash flow and debris flow deposits, and to estimate their emplacement temperature: 1991-1995 lava dome eruption at Mt. Unzen Volcano, Japan". Journal of Volcanology and Geothermal Research 303, pp. 92-111. DoI: 10.1016/ j . jvolgeores.2015.07.019.

Vallance, J. W. and R. M. Iverson (2015). "Lahars and Their Deposits". The Encyclopedia of Volcanoes. Ed. by H. Sigurdsson, B. Houghton, S. McNutt, H. Rymer, and J. Stix. Elsevier, pp. 649-664. DoI: $10.1016 /$ b978-0-12-385938-9.00037-7.

Watson, G. S. (1956). "A test for randomness fo directions". Geophysical Journal International 7, pp. 160161. DoI: 10.1111/ j . 1365-246x. 1956 . tb05561.x. 